\title{
Physicochemical Characteristics of Mauritia arabica Shell with High Temperature Calcination
}

\author{
Di Zhang1, Jiaxin Yao1, Yingli Wang2* \\ ${ }^{1}$ Department of Chemistry, Shanxi Medical University, Taiyuan, China \\ ${ }^{2}$ Shanxi University of Traditional Chinese Medicine, Jinzhong, China \\ Email: * zhangdi0801@live.cn
}

How to cite this paper: Zhang, D., Yao, J.X. and Wang, Y.L. (2019) Physicochemical Characteristics of Mauritia arabica Shell with High Temperature Calcination. Advances in Biological Chemistry, 9, 157-166. https://doi.org/10.4236/abc.2019.95012

Received: September 17, 2019

Accepted: October 26, 2019

Published: October 29, 2019

Copyright (c) 2019 by author(s) and Scientific Research Publishing Inc. This work is licensed under the Creative Commons Attribution International License (CC BY 4.0).

http://creativecommons.org/licenses/by/4.0/

\begin{abstract}
Mauritia arabica shell (MAS), is widely applied as a Chinese tradition medicine after thermal decomposition. However, it is still uncertain how the thermal decomposition process affects the physicochemical properties of MAS. Moreover, the influences of these properties on the bioavailability have not been well understood. In this investigation, a temperature-programmed pyrolysis process is applied to calcine MAS to achieve the desired MAS with different physicochemical properties. The results showed that a weight loss of $43.27 \%-44.73 \%$ was detected after MAS was calcined at $900^{\circ} \mathrm{C}$, which was mainly attributed to the decomposition of protein, the phase transition of calcium carbonate from aragonite to calcite, and the decomposition of calcium carbonate. The activation energy in the heating duration was calculated by applying the Kissinger-Akahira-Sunose model (KAS), which was $58.13 \mathrm{~kJ} / \mathrm{mol}$ for crystalline transformation and $181.27 \mathrm{~kJ} / \mathrm{mol}$ for decomposition. Besides, according to the analyses from Fourier transform infrared (FTIR) and X-ray powder diffraction (XRD) tests, the crystalline of calcium carbonate in MAS was aragonite. These results provide beneficial temperature parameters for the pretreatments of MAS for pharmaceutical usages.
\end{abstract}

\section{Keywords}

Mauritia arabica Shell, Calcined, Microstructure, Phase Change

\section{Introduction}

Mauritia arabica is mainly distributed on the coast of southeastern China, in rocky or coral reef substrate around the low tide zone [1]. It is harvested either in summer or autumn, and applied as the raw Chinese tradition medicine 
(TCM) after the flesh is removed, the left shells are washed, dried and mashed. The preparation of MAS as medicine can refer to the appendix IID in the Pharmacopoeia of the People's Republic of China. Briefly, the small pieces of dried and mashed MAS are calcined first above $600^{\circ} \mathrm{C}$ in furnaces or reactors and then cooled down to room temperature. The resulted fragile MAS are granulated into powder before extraction to make into the "medicinal cocktail".

Research shows that the major components of MAS are calcium carbonate (95.82\% - 97.24\%), protein (about 0.5\%) and trace elements (about 2\%) etc. The main elementary of MAS extraction are $\mathrm{Al}, \mathrm{Fe}, \mathrm{Na}, \mathrm{Mn}, \mathrm{K}, \mathrm{Mg}$ and $\mathrm{Ba}$. Aspartic acid, Glutamic acid, Glycine and leucine are the dominating ones among the whole sixteen types of amino acids from protein [2]. An ancient TCM book Qian Xin Yao Fang recorded that the extractions from calcined MAS have different medical functions compared to the un-calcined extractions. Therefore, it is greatly important to explore the MAS calcination processes for pharmaceutical usages and their influences on their biological functions. On the other hand, it is known that feeding hypertensive rats with the extracted water extraction from MAS led to the decreased blood pressure [3]. However, the chemistry and physics characteristic changes between un-calcined and calcined MAS remain unclear. In this investigation, the calcined pyrolysis of MAS utilizing thermal analyses including thermogravimetry (TG) and derivative thermogravimetry (DTG) was studied. The relevant kinetic characteristics were also identified to provide potential guidelines for the optimal pyrolysis temperature to convert MAS into functional biomedicine materials.

\section{Material and Methods}

\subsection{MAS Decomposition and TG/DTG Analysis}

MAS were purchased from Tong Ren Tang Pty Ltd (China) and granulated into fine powders (particle size less than $0.149 \mathrm{~mm}, 100 \mathrm{mesh}$ ). The experimental apparatus performing TG/DTG analysis was a NETZSCH TG/DTA model STA409C analyzer (Netzsch Inc., Selb, Germany). About $10 \mathrm{mg}$ of MAS samples were performed in the furnace of the thermobalance under the programming temperature from room temperature to $900^{\circ} \mathrm{C}$ at heating rates of $5^{\circ} \mathrm{C} / \mathrm{min}, 10^{\circ} \mathrm{C} / \mathrm{min}$, $20^{\circ} \mathrm{C} / \mathrm{min}$ in air. The experiment sweeping gas was high purity $\mathrm{N}_{2}$ at a flowing rate of $70 \mathrm{~mL} / \mathrm{min}$ in ambience pressure.

\subsection{Kinetic Analysis of the MAS Decomposition Process}

The decomposition reaction rate of MAS can be described by KAS equation [4] [5] shown by Equation (1), as the main composition in MAS is calcium carbonate. And the decomposition reaction rate also can be described by Ozawa-Flynn-Wall (OFW) equation [6] [7] shown by Equation (2):

$$
\ln \left(\frac{\beta_{i}}{T^{2}}\right)=\text { Const }-\frac{E_{a}}{R T}
$$




$$
\ln \beta=\ln \left[\frac{A E_{a}}{R G(\alpha)}\right]-5.3305-1.0516 \frac{E_{a}}{R T}
$$

where, $\beta$ is the heating rate, $T$ is the absolute temperature in $\mathrm{K}, E_{a}$ is the activation energy of the reaction, $\alpha$ is the degree of conversion value, $A$ is Arrhenius parameter, $R$ is the universal constant.

For KAS equation, each $\alpha, \ln \left(\beta_{i} / T^{2}\right)$ is plotted vs. $1 / T$, gives a straight line with slope $E_{a} / \mathrm{R}$, and thus the values $E a$ are obtained as a function of the conversion. For OFW equation each $\alpha, \ln \left(\beta_{i}\right)$ is plotted vs. $1 / T$, also gives a straight line with slope $-1.0516 E_{a} / \mathrm{R}$, and thus the values $E a$ are obtained.

\subsection{Physicochemical Characterizations}

According to the Chinese Pharmacopoeia, $600^{\circ} \mathrm{C}$ is the lowest calcined temperature. To obtained the different calcined MAS, MAS was heated in air at the rate of $10^{\circ} \mathrm{C} / \mathrm{min}$ from room temperature until $600^{\circ} \mathrm{C}$ and $800^{\circ} \mathrm{C}$, held for $1 \mathrm{~h}$ before cooling with pure nitrogen, respectively. The resulted calcined MAS samples, named MAS600 and MAS800, their physicochemical properties were further analyzed.

For FTIR spectroscopic characterization, approximately $1 \mathrm{mg}$ of MAS or calcined MAS sample was grinded with approximately $100 \mathrm{mg}$ of spectroscopic-grade $\mathrm{KBr}$, and then was pressed into $1 \mathrm{~mm}$ pellets. The analysis was conducted by a FTIR spectrometer equipped with a DTGS detector (MB104, ABB Bomen Co., Quebec, Canada). Each spectrum was recorded at the resolution of 4 $\mathrm{cm}^{-1}$ with 64 co-added scans in a frequency range of 500 to $4000 \mathrm{~cm}^{-1}$. The FTIR data was collected by Spectrum v5.0 software from Perkin Elemer company (USA). OMNIC 6.0 software (Thermo Electron Corporation, Madison, WI, USA) was applied to report the data, including baseline fitting with automatic smooth and min-max normalization of $4000 \mathrm{~cm}^{-1}$.

Scanning electron microscopy (SEM) and energy dispersive spectroscopy (EDS) obvervation were carried out using a Scanning Electron Microscope JEOL JSM-76360LV instrument equipped with X-ray powder diffraction (XRD) tests. For SEM analysis, the operating voltage was from 10 to $20 \mathrm{kV}$. XRD patterns were collected on a diffractometer (D/max 2500, Japan, Rigaku) with $\mathrm{Cu} \mathrm{Ka}$ radiation $(\lambda=1.5406 \AA)$ at room temperature. The operating voltage and current were $36 \mathrm{kV}$ and $30 \mathrm{~mA}$, respectively, and the scan speed was $2^{\circ} / \mathrm{min}$ in the two-theta range of $15^{\circ}-60^{\circ}$.

\section{Results and Discussion}

\subsection{MAS Decomposition Process}

MAS was calcined from room temperature to $900^{\circ} \mathrm{C}$ at different heating rates $(\beta)$ of $5^{\circ} \mathrm{C} / \mathrm{min}, 10^{\circ} \mathrm{C} / \mathrm{min}$, and $20^{\circ} \mathrm{C} / \mathrm{min}$, respectively. TG and DTG analyses were displayed in Figure 1 and the decomposition characteristic parameters of specific MAS pyrolysis were listed in Table 1. 

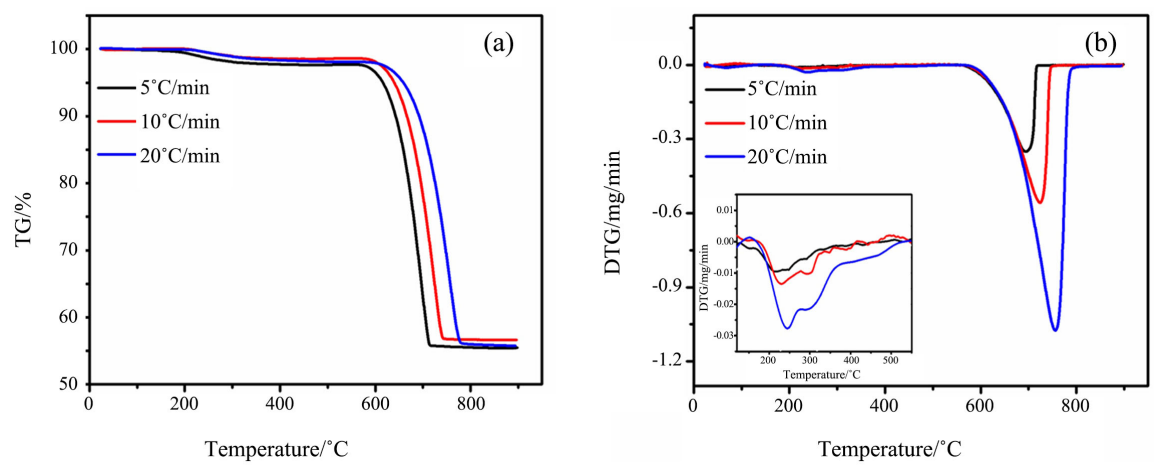

Figure 1. TG/ DTG curves for MAS samples at different heating rate. (a) TG curves; (b) DTG curves (inlet figure shows the scaled second stage of mass weight loss).

Table 1. Specific characteristic parameters of MAS thermal decomposition.

\begin{tabular}{cccccccccccccccc}
\hline $\begin{array}{c}\mathrm{B} \\
\left({ }^{\circ} \mathrm{C} / \mathrm{min}\right)\end{array}$ & $\begin{array}{c}\mathrm{Ti} \\
\left({ }^{\circ} \mathrm{C}\right)\end{array}$ & $\begin{array}{c}\mathrm{Tp} \\
\left({ }^{\circ} \mathrm{C}\right)\end{array}$ & $\begin{array}{c}\mathrm{Te} \\
\left({ }^{\circ} \mathrm{C}\right)\end{array}$ & $\begin{array}{c}\mathrm{Mass} \\
\%\end{array}$ & $\begin{array}{c}\mathrm{Ti} \\
\left({ }^{\circ} \mathrm{C}\right)\end{array}$ & $\begin{array}{c}\mathrm{Tp} \\
\left({ }^{\circ} \mathrm{C}\right)\end{array}$ & $\begin{array}{c}\mathrm{Te} \\
\left({ }^{\circ} \mathrm{C}\right)\end{array}$ & $\begin{array}{c}\text { Mass } \\
\%\end{array}$ & $\begin{array}{c}\mathrm{Ti} \\
\left({ }^{\circ} \mathrm{C}\right)\end{array}$ & $\begin{array}{c}\mathrm{Tp} \\
\left({ }^{\circ} \mathrm{C}\right)\end{array}$ & $\begin{array}{c}\mathrm{Te} \\
\left({ }^{\circ} \mathrm{C}\right)\end{array}$ & $\begin{array}{c}\text { Mass } \\
\%\end{array}$ & $\begin{array}{c}\mathrm{Mt} \\
\%\end{array}$ \\
\hline \multicolumn{1}{c}{ First } & \multicolumn{7}{c}{ Second } & \multicolumn{7}{c}{ Third } \\
\hline 5 & 22 & 50 & 125 & 0.16 & 125 & 206 & 553 & 1.14 & 553 & 699 & 722 & 41.80 & 44.40 \\
10 & 22 & 48 & 130 & 0.13 & 130 & 230 & 553 & 1.22 & 553 & 724 & 790 & 41.92 & 43.27 \\
20 & 22 & 68 & 130 & 0.04 & 130 & 232 & 553 & 1.79 & 553 & 756 & 800 & 42.17 & 44.00 \\
\hline
\end{tabular}

${ }^{\star} \mathrm{T}_{\mathrm{i}}$, the initial decomposition temperature; $T_{\mathrm{p}}$, the temperature of maximum weight loss rate; $T_{\mathrm{e}}$, the end temperature of the stage; Mass\%, the weight loss at the stage; $\mathrm{Mt} \%$, the total loss.

In the temperature-programmed pyrolysis process, MAS was gradually calcined with protein thermal decomposition and phase transition. As shown in Figure 1(a), the major mass weight loss commences at about $600^{\circ} \mathrm{C}$ and ends at around $800^{\circ} \mathrm{C}$ with different heating rates. Moreover, MAS pyrolysis has three stages (Figure $1(\mathrm{~b})$ ). The first stage starts from the room temperature till $142^{\circ} \mathrm{C}$ with the mass weight loss of $0.04 \%-0.26 \%$; the second stage of weight loss of $1.14 \%-2.37 \%$ ranging from $270^{\circ} \mathrm{C}$ to $553^{\circ} \mathrm{C}$ and the third weight loss of $43.27 \%-44.73 \%$ between $600^{\circ} \mathrm{C}$ and $800^{\circ} \mathrm{C}$. The first stage of the weight loss signified the water evaporation in the shell. Besides, the second stage is corresponding to the decomposition of organics and the endothermic phase transformation from aragonite crystal to calcite crystal. It is reported that the natural aragonite phase of $\mathrm{CaCO}_{3}$ transition temperature ranges from $450^{\circ} \mathrm{C}$ to $500^{\circ} \mathrm{C}$ [8]. Moreover, the phase transition of aragonite to calcite in cockle shell, coral and other marine shells, occurs at a lower temperature than that of the phase transition in aragonite of mineral origin [9] [10] [11]. The third mass loss stage starts at around $600^{\circ} \mathrm{C}$ and ends at $800^{\circ} \mathrm{C}$, which varied according to the heating rate. As shown in Figure $1(\mathrm{~b})$, at the heating rate of $5^{\circ} \mathrm{C} / \mathrm{min}$, the peak temperature is $699^{\circ} \mathrm{C}$ with the maximum weight loss rate of $-0.358 \mathrm{mg} / \mathrm{min}$. When the heating rate is $10^{\circ} \mathrm{C} / \mathrm{min}$ and $20^{\circ} \mathrm{C} / \mathrm{min}$, the peak temperature is $724^{\circ} \mathrm{C}$ with maximum weight loss rate of $-0.555 \mathrm{mg} / \mathrm{min}$, and the peak temperature is $773^{\circ} \mathrm{C}$ 
with maximum weight loss rate of $-1.464 \mathrm{mg} / \mathrm{min}$, respectively. The results indicate the total decomposition of calcium carbonate in MAS to $\mathrm{CaO}$ and signify the release of $\mathrm{CO}_{2}$ from calcium carbonate. Meanwhile, it was assumed that the rapid heating rate could accelerate the decomposition of the organic compounds in the shell, which in turn required higher decomposition temperatures.

\subsection{Kinetic Analysis of MAS Decomposition}

Further dynamics analysis was conducted by applying the KAS model to calculate the activation energy at different decomposition stages. Based on the Equations (1) and (2), the linear plots of $\ln \left(\beta_{i} / T^{2}\right)$ or $\ln \left(\beta_{i}\right)$ vs. the inverse temperature and the activation energy Ea values obtained as a function of the conversion are shown in Figure 2 and Figure 3. The calculated activation energy of the second and third stages of decomposition using KAS and OFW method is shown in Figure 4.

As shown in Figure 4(a), at the second stage of protein decomposition and phase transition, the average $E_{a}$ value is $58.13 \mathrm{~kJ} / \mathrm{mol}$ (average R $=0.947, \mathrm{KAS}$ method) and $64.34 \mathrm{~kJ} / \mathrm{mol}$ (average $\mathrm{R}=0.963$, OFW method), respectively. Comparing with the literature reports, the average Ea value is higher than the biomaterial with more plant proteins, whose Ea value calculated by CoastsRedfern (CR) method is $81 \mathrm{~kJ} / \mathrm{mol}$ in $200^{\circ} \mathrm{C}-460^{\circ} \mathrm{C}$ [12]. The third stage of calcination corresponds to the decomposition of $\mathrm{CaCO}_{3}$. The average $E_{a}$ value of MAS decomposition is $181.27 \mathrm{~kJ} / \mathrm{mol}$ (average $\mathrm{R}=0.969$, KAS method) and $188.47 \mathrm{~kJ} / \mathrm{mol}$ (average $\mathrm{R}=0.972$, OFW method), respectively. Comparing with the literature reports, the average Ea value of pure calcium carbonate decomposition calculated by OFW method is $203 \mathrm{~kJ} / \mathrm{mol}$ and $194.1 \mathrm{~kJ} / \mathrm{mol}$ (Friedman method) [13]. It shows that the average activation energy of MAS decomposition is generally lower than that of the pure calcium carbonate decomposition, because MAS contains not only calcium carbonate, but also organic macromolecules, such as amino acid and trace elements, which may play important roles in medication. Therefore, the elements retained in MAS before and after calcination are further measured by FTIR and XDR in the following.
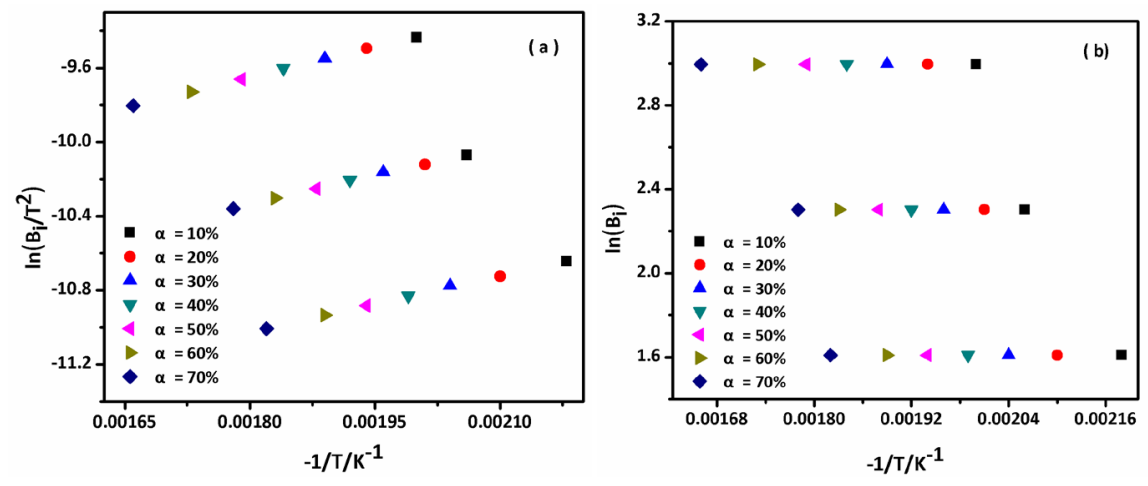

Figure 2. Fitting curves to kinetic model proposed by KAS (a) and OFW (b) method at the second stage of decomposition. 

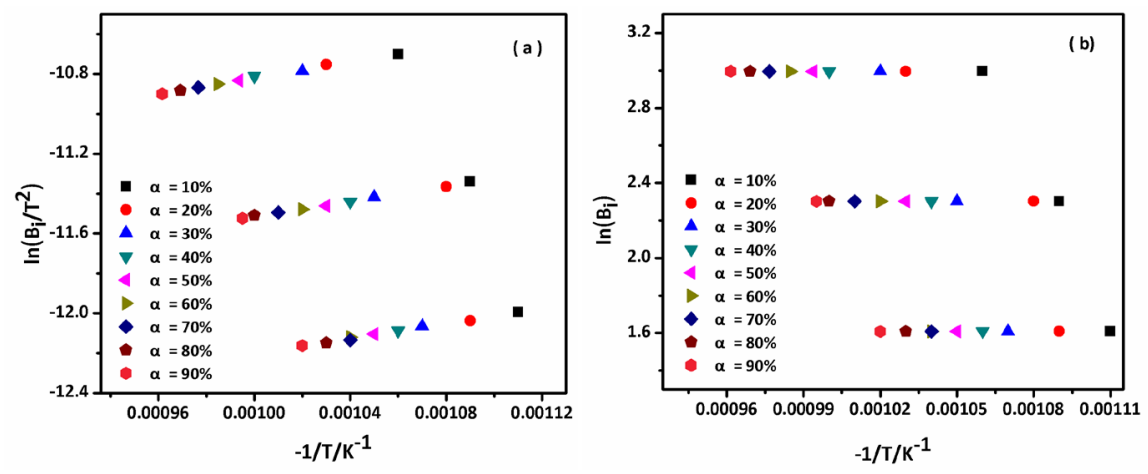

Figure 3. Fitting curves to kinetic model proposed by KAS (a) and OFW (b) method at the third stage of decomposition.
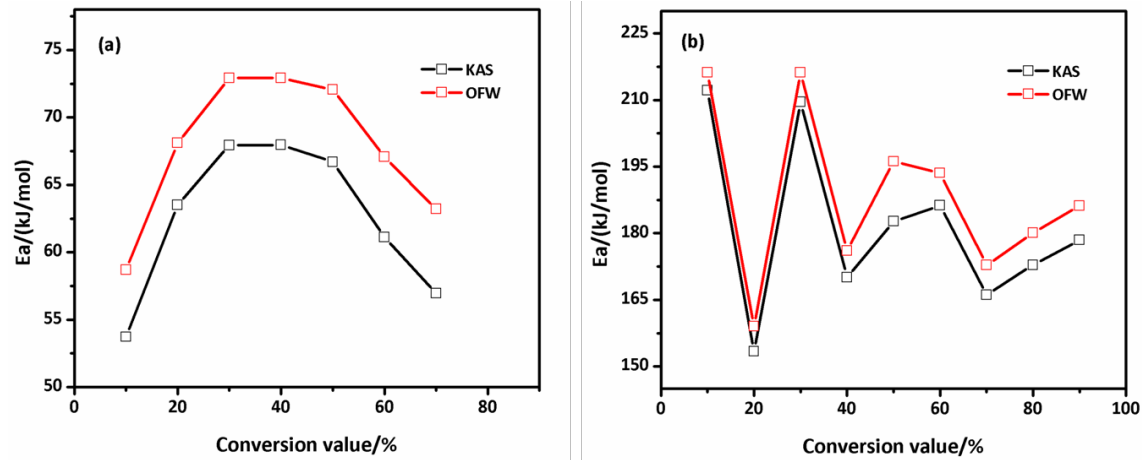

Figure 4. Ea valune-activation energy of MAS pyrolysis proposed by KAS and OFW method. (a) Second stage decomposition; (b) third stage decomposition.

\subsection{FTIR Analyses}

To fully understand the function ingredients of MAS as a medicine, the compositions of MAS before and after calcination are further identified by FTIR tests. In Figure 5, the comparison of FTIR spectra between untreated and calcined MAS in the range of $4000-500 \mathrm{~cm}^{-1}$ was illustrated.

The major components of MAS are calcium carbonate. The carbonate ions in the MAS are demonstrated by the internal vibration modes of the $\mathrm{CO}_{3}^{2-}$ ions, $710 \mathrm{~cm}^{-1}\left(\gamma_{4} \mathrm{CO}_{3}^{2-}\right), 860 \mathrm{~cm}^{-1}\left(\gamma_{2} \mathrm{CO}_{3}^{2-}\right), 1082 \mathrm{~cm}^{-1}\left(\gamma_{1} \mathrm{CO}_{3}^{2-}\right), 1477 \mathrm{~cm}^{-1}\left(\gamma_{3}\right.$ $\left.\mathrm{CO}_{3}^{2-}\right), 1789 \mathrm{~cm}^{-1}\left(\gamma_{3} \mathrm{CO}_{3}^{2-}\right)$, and $2521 \mathrm{~cm}^{-1}\left(\gamma_{1}+\gamma_{3}\right)$ [14]. The characteristic absorption peaks of aragonite $\mathrm{CaCO}_{3}$ are at $862 \mathrm{~cm}^{-1}\left(\gamma_{2} \mathrm{CO}_{3}^{2-}\right)$ and $712 \mathrm{~cm}^{-1}$ $\left(\gamma_{4} \mathrm{CO}_{3}^{2-}\right)$ [15]. MAS FTIR band at $860 \mathrm{~cm}^{-1}\left(\gamma_{2} \mathrm{CO}_{3}^{2-}\right)$ and $710 \mathrm{~cm}^{-1}\left(\gamma_{4}\right.$ $\mathrm{CO}_{3}^{2-}$ ) are attributed to the strong complexation of aragonite crystal in MAS with organic species. Compared to the untreated MAS, the absorption band of $\mathrm{CO}_{3}^{2-}$ ions at $860 \mathrm{~cm}^{-1}\left(\gamma_{2} \mathrm{CO}_{3}^{2-}\right)$, is shifted to $874 \mathrm{~cm}^{-1}$ in MAS600 and MAS800, and the band at $1477 \mathrm{~cm}^{-1}\left(\gamma_{3} \mathrm{CO}_{3}^{2-}\right)$ is shifted to $1437 \mathrm{~cm}^{-1}$ for MAS600 and $1429 \mathrm{~cm}^{-1}$ for MAS800, respectively. The internal vibration modes of the untreated MAS $\mathrm{CO}_{3}^{2-}$ ions at $1082 \mathrm{~cm}^{-1}\left(\gamma_{1} \mathrm{CO}_{3}^{2-}\right)$ are not detected in MAS600 and MAS800 and $2521 \mathrm{~cm}^{-1}\left(\gamma_{1}+\gamma_{3}\right)$ bands are shifted to $2514 \mathrm{~cm}^{-1}\left(\gamma_{1}\right.$ $\left.\mathrm{CO}_{3}^{2-}\right)$ in MAS600 and MAS800. FTIR spectra of calcite $\mathrm{CaCO}_{3}$ shows that the absorption bands are at the wavenumber $710 \mathrm{~cm}^{-1}\left(\gamma_{4} \mathrm{CO}_{3}^{2-}\right), 875 \mathrm{~cm}^{-1}\left(\gamma_{2}\right.$ 
$\left.\mathrm{CO}_{3}^{2-}\right), 1427 \mathrm{~cm}^{-1}\left(\gamma_{3} \mathrm{CO}_{3}^{2-}\right), 1800 \mathrm{~cm}^{-1}\left(\gamma_{3} \mathrm{CO}_{3}^{2-}\right)$ and $2513 \mathrm{~cm}^{-1}\left(\gamma_{1}+\gamma_{3}\right)$. Considering that the phase transition of aragonite temperature ranges from $270^{\circ} \mathrm{C}$ to $360^{\circ} \mathrm{C}$, the $\mathrm{CaCO}_{3}$ in MAS600 and MAS800 is in the phase of calcite. Furthermore, the peak at $3639 \mathrm{~cm}^{-1}$ is assigned to the $\mathrm{OH}$ group and narrowed significantly, due to the water evaporation, but some remains in the porous calcinated shell [16]. Besides, the calcination to $800^{\circ} \mathrm{C}$ leads to further break down of organic species,

\subsection{SEM-EDS Analysis}

The morphology and structure of untreated and calcined MAS were further observed by scanning electron microscopy (SEM) and shown in Figure 6. It demonstrates the particle morphology of un-treaded MAS (Figure 6(a)). MAS is constructed as "brick-mortar" microstructure in which the brick is the organic-minerals containing inorganic components, such as amino acids as the mortar. The particle patterns of MAS600 and MAS800 in Figure 6(b) and Figure 6 (c), indicate the decomposition products have similar particles morphology. The most obvious difference is that the "mortar" microstructure is disappeared and covered by a layer of small particles. Meanwhile, the number of the small particles is increased in MAS800.

By EDS measurements, the difference in major elements between un-calcined and calcined samples was identified (Figure 7). It can be seen that in uncalcined shell, the elements such as $\mathrm{Ca}, \mathrm{K}, \mathrm{P}$ and $\mathrm{Na}$ were detected in the shell, but their concentrations decrease after heating, except $\mathrm{Ca}$. Moreover, the signal of element $\mathrm{Ca}$, which has a significant enhancement after calcination, can be attributed to the decomposition of $\mathrm{CaCO}_{3}$ [17].

\subsection{XRD Analysis}

The X-ray powder diffraction (XRD) patterns of un-calcined and calcined MAS were collected (Figure 8), where the diffraction pattern of un-clacined MAS with the peaks of (111), (021) and (012). They match with the JCPDS PDF file No.

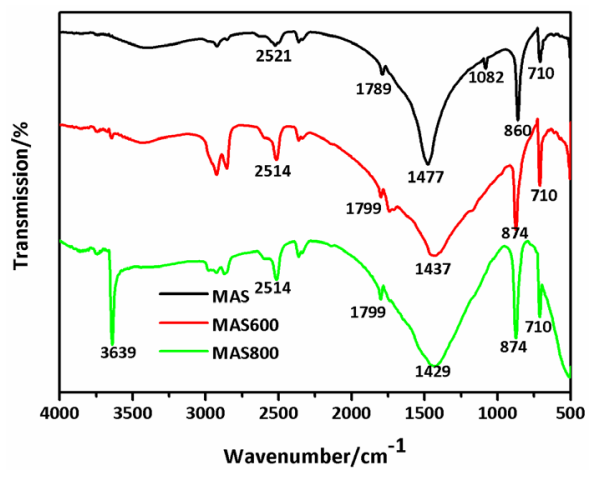

Figure 5. FTIR spectra of MAS samples calcined at different temperature. MAS: un-calcined Mauritia arabica shell; MAS600: Mauritia arabica shell calcined at $600^{\circ} \mathrm{C}$; MAS800: Mauritia arabica shell calcined at $800^{\circ} \mathrm{C}$. 


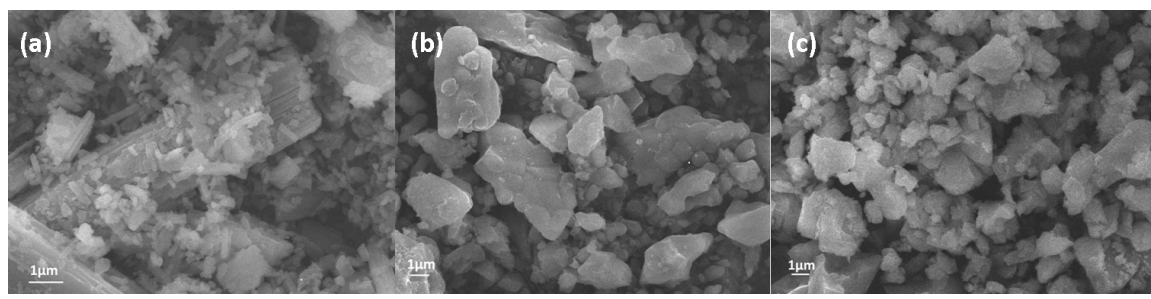

Figure 6. SEM images of un-calcined and calcined MAS. (a) MAS: un-calcined Mauritia arabica shell; (b) MAS600: Mauritia arabica shell calcined at $600^{\circ} \mathrm{C}$; (c) MAS800: Mauritia arabica shell calcined at $800^{\circ} \mathrm{C}$.

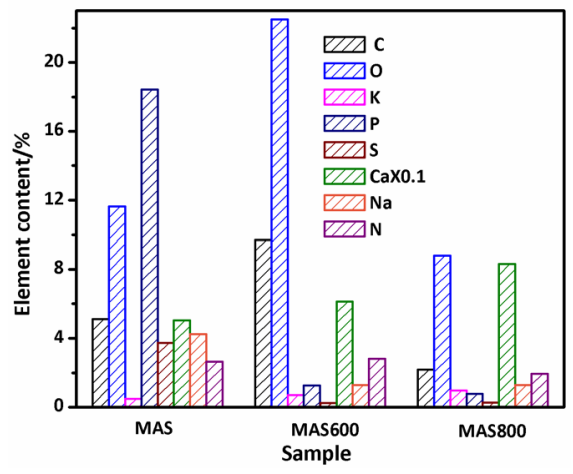

Figure 7. Major elements contents of samples from EDS spectrum.

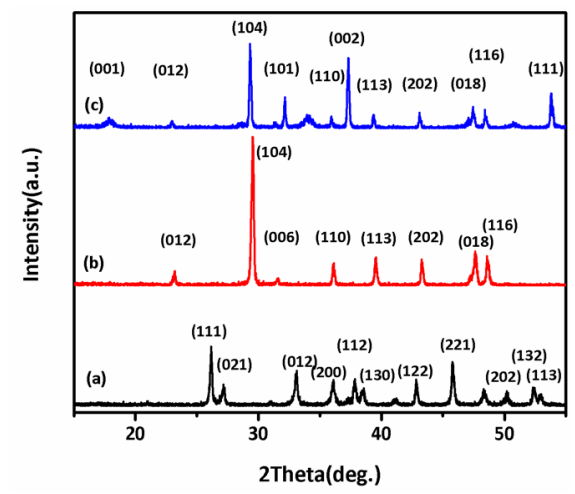

Figure 8. The XRD patterns of different samples.

41-1475 (aragonite $-\mathrm{CaCO}_{3}$ ) indicating that the phase of $\mathrm{CaCO}_{3}$ in un-calcined MAS is only aragonite. The strongest diffraction peak of aragonite in MAS is (111) crystal peak. Figure 8(b) shows the MAS600 diffraction pattern, which matches the JCPDS PDF file No. 05-0586 (calcite- $\mathrm{CaCO}_{3}$ ). The strong peak of (104), five medium peaks (110), (113), (202), (018), (116) and two weak peaks (012), (006) in MAS600 indicate that aragonite is disappeared and more stable phase calcite $\mathrm{CaCO}_{3}$ in MAS600 appeared. Figure 8(c) shows the diffraction pattern of MAS800. This pattern matches two JCPDS PDF files No. 05-0586 (calcite- $\mathrm{CaCO}_{3}$ ) and No. 04-0733 (portlandite- $\mathrm{Ca}(\mathrm{OH})_{2}$ ). The peaks of (001), (101), (002) and (111) indicate that $\mathrm{Ca}(\mathrm{OH})_{2}$ appeared, which resulted from two reactions $\mathrm{CaCO}_{3} \rightarrow \mathrm{CaO}+\mathrm{CO}_{2}$ and $\mathrm{CaO}+\mathrm{H}_{2} \mathrm{O} \rightarrow \mathrm{Ca}(\mathrm{OH})_{2}$ [18] [19] [20] [21] 
[22]. XRD results are well consistent with FTIR results shown in Figure 5.

\section{Conclusion}

Mauritia arabica shell (MAS) has a laminated structure and the major components are calcium carbonate and protein. Calcination process is an important operation for taking natural Mauritia arabica shell as raw Chinese traditional medicine in pharmaceutical engineering. The pyrolysis corresponds mainly to the decomposition of protein, the phase transition of calcium carbonate from aragonite to calcite, and the decomposition of calcium carbonate. The activation energy in the heating duration is $58.13 \mathrm{~kJ} / \mathrm{mol}$ for crystalline transformation and $181.27 \mathrm{~kJ} / \mathrm{mol}$ for decomposition respectively, by applying the KAS model. At around $553^{\circ} \mathrm{C}$, the endothermic phase transformation from aragonite crystal to calcite crystal is completely finished. At $600^{\circ} \mathrm{C}$, the calcium carbonate in MAS begins to decompose. In conclusion, the present study provides valuable information for the determination of calcination temperatures in the pharmaceutical treatments of MAS.

\section{Acknowledgements}

This work is financially supported by the China Scholarship Fund (20135045).

\section{Conflicts of Interest}

The authors declare no conflicts of interest regarding the publication of this paper.

\section{References}

[1] Huang, C.H., Zhu, S.X., Lin, J.D. and Dong, Q.X. (2008) Imposex of Mauritia arabica on the South-Eastern Coast of China. Journal of the Marine Biological Association of the United Kingdom, 88, 1451-1457. https://doi.org/10.1017/S0025315408002075

[2] Zhang, S.Q., Li, W.X., Li, L. and Ren, T. (1994) Assay of the Chemical Composition in Chinese Medicine Monetarla Moneta. China Journal of Chinese Materiamedica, 8, 471-510.

[3] Peng, Q.Q., Hong, Y. and Liao, G.H. (2014) Experimental Study of Six Testacean TCM on the Mechanism of "Calming the Liver and Suppressing Yang" in Rats with Hypertension of Hyperactivity of Liver Yang. Journal of Emergency in Traditional Chinese Medicine, 23, 1016-1018.

[4] Brown, M.E. and Maciejewski, M. (2000) Computational Aspects of Kinetic Analysis Part A: The ICTAC Kinetics Project-Data, Methods and Results. Thermochimica Acta, 355, 125-143. https://doi.org/10.1016/S0040-6031(00)00444-5

[5] Sergey, V. and Alan, K.B. (2011) ICTAC Kinetics Committee Recommendations for Performing Kinetic Computations on Thermal Analysis Data. Thermochimica Acta, 520, 1-19. https://doi.org/10.1016/j.tca.2011.03.034

[6] Zhang, L., Tian, Y. and Lu, C.M. (2011) Thermogravimetric Analysis and Study on Calcination Kinetics of Industrial Wastes. Journal of China Coal Society, 36, 681-686.

[7] Rao, T.R. (1996) Kinetics of Calcium Carbonate Decomposition. Chemical Engineering \& Technology, 19, 373-377. https://doi.org/10.1002/ceat.270190411 
[8] Baumer, A., Ganteaume, M. and Bernat, M. (1993) Variations de la teneur en eau des coraux lors de la transformation aragonite-calcite. Thermochimica Acta, 221, 255-262. https://doi.org/10.1016/0040-6031(93)85070-P

[9] Ren, F.Z., Wan, X.D., Ma, Z.H. and Su, J.H. (2009) Study on Microstructure and Thermodynamics of Nacre in Mussel Shell. Materials Chemistry and Physics, 114, 367-370. https://doi.org/10.1016/j.matchemphys.2008.09.036

[10] Kamba, A.S., Ismail, M., Ibrahim, T.A.T. and Zakaria, Z.A.B. (2013) Synthesis and Characterisation of Calcium Carbonate Aragonite Nanocrystals from Cockle Shell Powder (Anadara granosa). Journal of Nanomaterials, 2013, Article ID: 398357. https://doi.org/10.1155/2013/398357

[11] Linga Raju, C., Narasimhulu, K.V., Gopal, N.O., Rao, J.L. and Reddy, B.C.V. (2002) Electron Paramagnetic Resonance, Optical and Infrared Spectral Studies on the Marine Mussel Arca Burnesi Shells. Journal of Molecular Structure, 608, 201-211. https://doi.org/10.1016/S0022-2860(01)00952-8

[12] Liao, Y.F., Zeng, C.C., Ma, X.Q. and Song, J.H. (2013) Thermogravimetric Analysis of Pyrolysis and Combustion Characteristics of Typical Biomass in South China. Journal of South China University of Technology (Natural Science Edition), 41, 1-9.

[13] Chen, H.X. and Liu, N.A. (2010) Application of Non-Arrhenius Equations in Interpreting Calcium Carbonate Decomposition Kinetics: Revisited. Journal of the American Ceramic Society, 93, 548-553. https://doi.org/10.1111/j.1551-2916.2009.03421.x

[14] Lee, S.W., Kim, Y.M., Kim, R.H. and Choi, C.S. (2008) Nano-Structured Biogenic Calcite: A Thermal and Chemical Approach to Folia in Oyster Shell. Micron, 39, 380-386. https://doi.org/10.1016/j.micron.2007.03.006

[15] Da, Z.Z., Sun, D.M. and Wu, Q.S. (2011) Assembly of Ano-Superstructural Aragonite $\mathrm{CaCO}_{3}$ by Living Bio-Membrane. Journal of Experimental Nanoscience, 6, 622-630. https://doi.org/10.1080/17458080.2010.518167

[16] Giardina, M.A. and Fanovich, M.A. (2010) Synthesis of Nanocrystalline Hydroxyapatite from $\mathrm{Ca}(\mathrm{OH})_{2}$ and $\mathrm{H}_{3} \mathrm{PO}_{4}$ Assisted by Ultrasonic Irradiation. Ceramics International, 36, 1961-1969. https://doi.org/10.1016/j.ceramint.2010.05.008

[17] Liao, Q.L., Wang, F., Chen, K.R., Pan, S.Q., Zhu, H.Z., Lu, M.W. and Qin, J.F. (2015) FTIR Spectra and Properties of Iron Borophosphate Glasses Containing Simulated Nuclear Wastes. Journal of Molecular Structure, 1092, 187-191. https://doi.org/10.1016/j.molstruc.2015.03.034

[18] An, Y.L., Liu, Z.M. and Wu, W.J. (2013) Phase Transition of Aragonite in Abalone Nacre. Phase Transitions, 86, 391-395. https://doi.org/10.1080/01411594.2012.678007

[19] Zhang, G.S. and Xu, J. (2013) From Colloidal Nanoparticles to a Single Crystal: New Insights into the Formation of Nacre's Aragonite Tablets. Journal of Structural Biology, 182, 36-43. https://doi.org/10.1016/j.jsb.2013.01.010

[20] Lin, Y.Y., Zhang, C., Zhang, J. and Zhang, M.C. (2011) XRD and FTIR Analysis of the Pyrolysis Products of Biomass Accompanied by Cao. Journal of Engineering Thermophysics, 32, 2133-2136.

[21] Wu, S.C., Shu, H.C., Wu, Y.N. and Ho, W.F. (2011) Hydroxyapatite Synthesized from Oyster Shell Powders by Ball Milling and Heat Treatment. Materials Characterization, 62, 1180-1187. https://doi.org/10.1016/j.matchar.2011.09.009

[22] Liu, R., Xu, X.R., Pan, H.H., Yan, W.Q. and Tang, R.K. (2012) Aragonite Crystals Formation on Nacre Substrate. Journal of Crystal Growth, 351, 41-46. https://doi.org/10.1016/j.jcrysgro.2012.04.013 